\title{
MERCURY QUANTIFICATION IN SOILS USING THERMAL DESORPTION AND ATOMIC ABSORPTION SPECTROMETRY: PROPOSAL FOR AN ALTERNATIVE METHOD OF ANALYSIS
}

\author{
Liliane Catone Soares ${ }^{(1) *}$, Fernando Barboza Egreja Filho ${ }^{(2)}$, Cláudia Carvalhinho \\ Windmoller ${ }^{(2)}$ and Maria Irene Yoshida ${ }^{(2)}$
}

(1) Universidade Federal de Minas Gerais, Instituto de Ciências Exatas, Departamento de Química, Programa de Pós-graduação em
Química, Belo Horizonte, Minas Gerais, Brasil.
${ }^{(2)}$ Universidade Federal de Minas Gerais, Instituto de Ciências Exatas, Departamento de Química, Belo Horizonte, Minas Gerais, Brasil.
* Corresponding author.
E-mail: liliane-catone@ufmg.br

\begin{abstract}
Despite the considerable environmental importance of mercury (Hg), given its high toxicity and ability to contaminate large areas via atmospheric deposition, little is known about its activity in soils, especially tropical soils, in comparison with other heavy metals. This lack of information about $\mathrm{Hg}$ arises because analytical methods for determination of $\mathrm{Hg}$ are more laborious and expensive compared to methods for other heavy metals. The situation is even more precarious regarding speciation of $\mathrm{Hg}$ in soils since sequential extraction methods are also inefficient for this metal. The aim of this paper is to present a technique of thermal desorption associated with atomic absorption spectrometry, TDAAS, as an efficient tool for quantitative determination of $\mathrm{Hg}$ in soils. The method consists of the release of $\mathrm{Hg}$ by heating, followed by its quantification by atomic absorption spectrometry. It was developed by constructing calibration curves in different soil samples based on increasing volumes of standard $\mathrm{Hg}^{2+}$ solutions. Performance, accuracy, precision, and quantification and detection limit parameters were evaluated. No matrix interference was detected. Certified reference samples and comparison with a Direct Mercury Analyzer, DMA (another highly recognized technique), were used in validation of the method, which proved to be accurate and precise.
\end{abstract}

Keywords: heavy metal, analytical method, weathered soils. 


\title{
RESUMO: QUANTIFICAÇÃO DE MERCÚRIO EM SOLOS POR TERMODESSORÇÃO ACOPLADA À ESPECTROMETRIA DE ABSORÇÃO ATÔMICA: PROPOSIÇÃO DE UM MÉTODO ALTERNATIVO DE ANÁLISE
}

\begin{abstract}
Apesar da grande importância ambiental do mercúrio (Hg), dada a sua elevada toxicidade e capacidade de contaminar extensas áreas via deposição atmosférica, pouco se conhece sobre seu comportamento em solos, especialmente nos tropicais, comparando-se com outros metais pesados. Certamente, essa escassez de informações ocorre porque os métodos de determinação de Hg são caros e laboriosos. Em relação à especiação do $\mathrm{Hg}$ em solos, a situação é mais precária, uma vez que os métodos de extração sequencial também são ineficientes para esse metal. Objetivou-se com este trabalho apresentar a técnica de termodessorção associada à espectrometria de absorção atômica, TDAAS, como ferramenta eficiente para a determinação quantitativa de $\mathrm{Hg}$ em amostras de solos. O método consiste na liberação de $\mathrm{Hg}$, por aquecimento, seguido da quantificação desse por espectrometria de absorção atômica, e foi desenvolvido construindo-se curvas de calibração em diferentes matrizes de solo, a partir de soluções-padrão de $\mathrm{Hg}^{2+}$. Os parâmetros de desempenho, exatidão, precisão, limites de detecção e quantificação foram avaliados. Não houve interferência da matriz no resultado. As amostras de referência certificadas e a comparação com a determinação direta de Hg, DMA, outra técnica consagrada, foram utilizadas na validação do método, que se evidenciou exato e preciso.
\end{abstract}

Palauras-chave: metal pesado, método analitico, solos intemperizados.

\section{INTRODUTION}

Mercury $(\mathrm{Hg})$ is a non-essential element and highly toxic heavy metal, and it has been considered a global pollutant due to its ability to reach long distance from the source of pollution by atmospheric transport (Wang et al., 2003).

In Brazil, small-scale gold mining operations are the main source of $\mathrm{Hg}$ dissemination in different environmental compartments (UNEP, 2008). Despite the ban on $\mathrm{Hg}$ use in mining, there are many contaminated soils in Minas Gerais, which is among the states with the largest number of operational gold mines in Brazil (DNPM, 2010).

In December 2002, citizens observed "silver balls" on the ground of a deactivated gold mine in the rural area of the municipality of Descoberto, Minas Gerais. Durão Júnior et al. (2009), studying soil samples from that area, identified samples with total $\mathrm{Hg}$ concentrations ranging from 0.0371 to $161 \mathrm{\mu g} \mathrm{g}^{-1}$, In addition to metallic $\mathrm{Hg}$ that surfaced, they identified large quantities of $\mathrm{Hg}^{2+}$, showing $\mathrm{Hg}^{0}$ oxidation in the soil.

Apart from anthropogenic contributions, the natural levels of $\mathrm{Hg}$ in soils from Minas Gerais vary widely, from very low levels $\left(0.02 \mathrm{\mu g} \mathrm{g}^{-1}\right)$ to extremely high values $\left(4.33 \mathrm{\mu g} \mathrm{g}^{-1}\right)$, as verified by a team that defined the reference values for heavy metal contents in soils in the State of Minas Gerais (Mello and Abrahão, 2013). The highest value is almost nine times greater than the $\mathrm{Hg}$ prevention value (the value above which there can be harmful alterations to soil quality) in the State of São Paulo (Cetesb, 2005). Since these soils with such high levels of $\mathrm{Hg}$ show abundant life, it is clear that the total concentration of metal in the soil is not sufficient to determine the risk of the metal to the environment. It is important to determine the bioavailability of chemical species present and their mobility and toxicity (Kim et al., 2003).

Sequential extraction has been used for fractionation of trace metals from the different environmental soil compartments, in which extractants selectively remove the metal associated with different fractions in descending order of availability. However, sequential extractions become inadequate due to the ease with which $\mathrm{Hg}$ undergoes redox reactions, through the generation of many artifacts associated with reduction of $\mathrm{Hg}^{2+}$ to $\mathrm{Hg}^{0}$, lost through volatilization or precipitated as compounds of $\mathrm{Hg}_{2}^{2+}$. Therefore, sequential extraction should be evaluated carefully. Given the limitations of sequential extraction for $\mathrm{Hg}$, associated with the low soil $\mathrm{Hg}$ content to be split into several fractions, thermal desorption atomic absorption spectrometry (TDAAS) has been used and developed as a qualitative $\mathrm{Hg}$ speciation technique (Valle et al., 2005; Rumayor et al., 2013, 2015).

The TDAAS technique is based on the thermal decomposition of compounds of $\mathrm{Hg}$ in several different states of oxidation, releasing $\mathrm{Hg}^{0}$ gas, which can be routed to a quartz tube where the light beam of a hollow cathode $\mathrm{Hg}$ lamp at 253.65 $\mathrm{nm}$ is focused. Part of the light beam is absorbed by the $\mathrm{Hg}^{0}$ vapor and the absorbance is measured by an atomic absorption spectrometer.

Little is known about the reduction mechanisms of $\mathrm{Hg}_{2}^{2+}$ and $\mathrm{Hg}^{2+}$ compounds to $\mathrm{Hg}^{0}$, although it is known that this mechanism depends on sample matrix composition and how the $\mathrm{Hg}$ binds to the 
mineral constituents of this matrix, which can be used for metal speciation, as shown by Valle et al. (2005) and Rumayor et al. (2013, 2015).

The quantitative aspect of the technique has been explored since 1904, in cinnabar mines (Henry et al., 1972). In the 1970s, methods of analysis were proposed in which the $\mathrm{Hg}^{0}$ gas generated by heating a sample was concentrated and then analyzed by cold vapor atomic absorption (Aston and Riley, 1972; Lidums, 1972) or against solid patterns of cinnabar and silica (Henry et al., 1972). Windmöller (1996) demonstrated that it was possible to construct TDAAS calibration curves with certified reference material yielding linearity up to $114 \mathrm{ng}$ of $\mathrm{Hg}$.

Valle et al. (2005), using model components, showed that the thermal desorption profiles of $\mathrm{Hg}$ bonded to different soil mineral phases are different among themselves, and are different from the thermal desorption profiles of $\mathrm{Hg}$ bonded to the soil organic phases. Since recent literature about this technique only provides qualitative results, the aim of this study was to develop and present the TDAAS as a quantitative technique for soil $\mathrm{Hg}$ analysis to be used both for quantification and speciation of the metal.

Not only is $\mathrm{Hg}$ fractionation more difficult, but determination of its total content does not occur with the same ease as for most other trace metals. The widely accepted technique, cold vapor atomic absorption spectrometry (CVAAS), is much more laborious and time consuming than usual determination by flame atomic absorption, and not all laboratories have the accessories and the qualifications required for such analysis. There is already equipment designed for direct $\mathrm{Hg}$ analysis by atomic absorption (DMA-80, Direct Mercury Analyzer) in the market and it does a quick scan, but it has a high upfront and operational cost and it is only applicable to samples with low $\mathrm{Hg}$ levels and only for total $\mathrm{Hg}$ quantification.
Despite its enormous environmental importance, because of the analytical difficulties inherent to this metal, there are not many studies in the literature assessing $\mathrm{Hg}$ in soils, especially in highly weathered tropical soils. Searching for the terms "mercury or $\mathrm{Hg}$ " and "tropical soil" in Web of Science, we found 2,826 articles for the period from 2002 to 2014, compared to 22,057 articles with the same terms but replacing "Hg" with " $\mathrm{Pb}$ ". If the word "speciation" is added to the search, the number of articles involving $\mathrm{Hg}$ reduces to one third, and the difference between the number of articles involving $\mathrm{Hg}$ and the number involving lead is even greater. This scarcity of studies about $\mathrm{Hg}$ can be seen in the very recent work by Preston et al. (2014), which sought quality reference values for heavy metals in soils in the State of Rio Grande do Norte and did not include $\mathrm{Hg}$ in the list of evaluated elements.

Given the potential for use for both total quantification and for $\mathrm{Hg}$ speciation in a quick manner (20 min), without sample preparation and at low cost, the TDAAS technique is presented in this article for the first time as an excellent option for quantitative analysis of $\mathrm{Hg}$ in soils, especially for soils with higher $\mathrm{Hg}$ levels, such as soils in the State of Minas Gerais.

\section{MATERIAL AND METHODS}

\section{Description of TDAAS equipment}

TDAAS analysis was performed using an atomic absorption spectrometer (CG Analytical model GBC 932 AA) with a thermal desorption system. This system consists of a quartz tube surrounded by a $\mathrm{Ni}-\mathrm{Cr}$ coil and an insulating material connected to a temperature controller (heating until $600{ }^{\circ} \mathrm{C}$ at a heating rate of $33^{\circ} \mathrm{C} \mathrm{min}-1$ ) and nitrogen as a carrier gas at a flow rate of $200 \mathrm{~mL} \mathrm{~min}^{-1}$. Figure 1 shows a schematic representation of the TDAAS system.

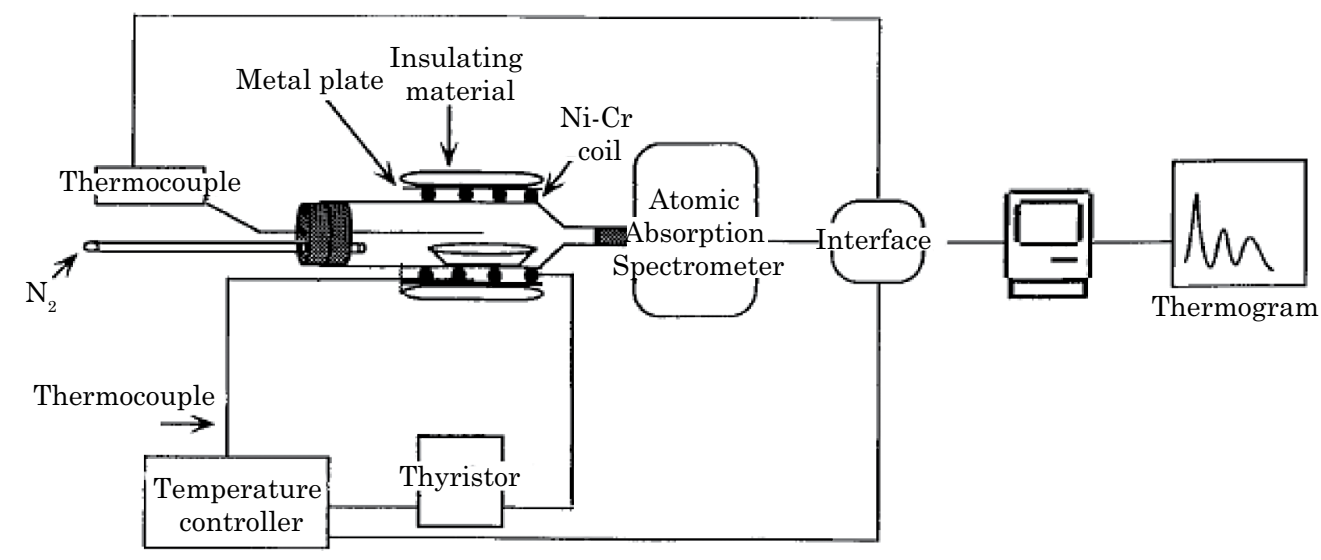

Figure 1. Schematic of equipment used for mercury thermal desorption of solid matrices by atomic absorption. Adapted from Windmöller (1996). 
Soil samples and standards were introduced in a ceramic refractory inside the quartz tube. The $\mathrm{Hg}^{0}$ released from the sample by heating the quartz tube was drawn by $\mathrm{N}_{2}$ flow to another quartz tube, which was subjected to an $\mathrm{Hg}$ radiation beam from a hollow cathode lamp and a deuterium lamp to correct the background. The purpose of background correction is to eliminate gas absorption bands $\left(\mathrm{CO}_{2}\right.$, $\mathrm{SO}_{2}, \mathrm{NO}_{\mathrm{x}}$, water vapor, and others) from the thermal decomposition of soil samples.

Absorbance signals were recorded as a function of temperature, and the thermograms have bands that were correlated to qualitative aspects of $\mathrm{Hg}$ species (Valle et al., 2005), while areas under the curves are proportional to the $\mathrm{Hg}$ content of the samples, which can be used for soil $\mathrm{Hg}$ quantification.

Thermograms were digitalized using the Digitize program and the areas under the curves were calculated using the Microcal Origin 8.0 program. Newer equipment, with software that exports the curve data, does not require the digitalization step.

\section{The samples}

The soil samples described in table 1 and the certified reference materials (CRMs), Montana Soil Nist-SRM $2711\left(6.25 \pm 0.19 \mu \mathrm{g} \mathrm{g}^{-1}\right.$ of $\left.\mathrm{Hg}\right)$ and River Sediment GBW-GBW 08301 RCV 8221 $\left(0.220 \pm 0.040 \mu \mathrm{g} \mathrm{g}^{-1}\right.$ of $\left.\mathrm{Hg}\right)$, were used to develop and validate the method. Certified reference materials were also used for accuracy evaluation, as will be detailed in the respective item.
Samples of the A and C horizons of RQo and the A and B horizons of other soils (Table 1) were collected from areas not affected either by agricultural or industrial activities, and they correspond to representative soils of the State of Minas Gerais with clayey, medium, and sandy textures.

Amounts of $1.0000 \mathrm{~g}$ of each sample were subjected to $\mathrm{Hg}$ adsorption with $20.00 \mathrm{~mL}$ of $0.1000 \mu \mathrm{g} \mathrm{mL} \mathrm{m}^{-1} \mathrm{Hg}^{2+}$ (which was prepared from a standard solution of $1,000 \mu \mathrm{g} \mathrm{mL}^{-1}$ for atomic absorption analysis). The samples were shaken for $12 \mathrm{~h}$ at $150 \mathrm{rpm}$ on a horizontal shaker (Tecnal), at room temperature.

In order to verify the proportionality of the results, samples of the A horizon of NVef incubated with $0.5000,1.0000$, and $2.0000 \mu \mathrm{g} \mathrm{mL}^{-1} \mathrm{Hg}^{2+}$ were also analyzed. After the adsorption period, the samples were centrifuged at $2493 \mathrm{~g}$ (3500 rpm - SIGMA Lab Centrifuge 6-15) for ten minutes. $\mathrm{Hg}$ levels in the supernatants were determined using the Direct Mercury Analyzer, DMA-80, from Milestone. The remaining solids were washed three times with ultrapure water $\left(\mathrm{k}=0.05 \mu \mathrm{S} \mathrm{cm}^{-1}\right)$, centrifuged and lyophilized. The adsorbed $\mathrm{Hg}$ concentrations were determined by TDAAS, and expected recoveries (total added $\mathrm{Hg}$ content minus the non-adsorbed $\mathrm{Hg}$ content) were evaluated. All analyses were performed in triplicate. In all cases, the $\mathrm{Hg}$ content determined by the TDAAS technique was calculated using the calibration curve as described below.

Table 1. Identification, classification, geographical location, and source material of soils used for the development and validation of the thermal desorption associated with atomic absorption spectrometry method

\begin{tabular}{|c|c|c|c|c|c|}
\hline Soil identification & Soil classification $^{(1)}$ & Horizon & Coordinates & Muncipality & Source material \\
\hline \multirow[t]{2}{*}{ PVA } & Typic Hapludult & $\mathrm{A}$ & $\mathrm{S} 20^{\circ} 45^{\prime} 14^{\prime \prime}$ & Viçosa & Stratified alluvial sediments \\
\hline & & & $\mathrm{W} 42^{\circ} 52^{\prime} 55$ & & \\
\hline \multirow[t]{2}{*}{$\mathrm{LVd}$} & Rhodic Hapludox & $\mathrm{A}$ & S $20^{\circ} 39^{\prime} 37^{\prime \prime}$ & Conselheiro & Limestone \\
\hline & & $\mathrm{B}$ & $\mathrm{W} 43^{\circ} 47^{\prime} 10^{\prime \prime}$ & Lafaiete & \\
\hline \multirow[t]{2}{*}{$\operatorname{LVAd}_{1}$} & Humic Xanthic & A & $\mathrm{S} 21^{\circ} 13^{\prime} 33^{\prime \prime}$ & Barbacena & Gneiss \\
\hline & & B & $\mathrm{W} 43^{\circ} 46^{\prime} 25^{\prime \prime}$ & & \\
\hline \multirow[t]{2}{*}{$\mathrm{LVj}$} & Humic Rhodic & A & S $19^{\circ} 59^{\prime} 08^{\prime \prime}$ & Nova Lima & Itabirite \\
\hline & & $\mathrm{B}$ & $\mathrm{W} 43^{\circ} 50^{\prime} 48^{\prime \prime}$ & & \\
\hline \multirow[t]{2}{*}{ NVef } & Typic Rhodudalf & A & $\mathrm{S} 21^{\circ} 00^{\prime} 28^{\prime \prime}$ & Guiricema & Basalt \\
\hline & & $\mathrm{B}$ & $\mathrm{W} 42^{\circ} 43^{\prime} 04^{\prime \prime}$ & & \\
\hline \multirow[t]{2}{*}{ CXbe } & Oxic Eutric & A & S $19^{\circ} 37^{\prime} 05^{\prime \prime}$ & Pedro & Limestone \\
\hline & Haplustept & B & $\mathrm{W} 44^{\circ} 02^{\prime} 35^{\prime \prime}$ & Leopoldo & \\
\hline \multirow[t]{2}{*}{$\mathrm{FFcd}_{1}$} & Petroferric Acrustox & A & $\mathrm{S} 17^{\circ} 04^{\prime} 53^{\prime \prime}$ & Brasilândia de & Tertiary and quaternary deposits \\
\hline & & $\mathrm{B}$ & $\mathrm{W} 46^{\circ} 00^{\prime} 16$ & Minas & $\begin{array}{l}\text { associated with pelitic rocks } \\
\text { (siltstones and slates) of the Bambuí }\end{array}$ \\
\hline \multirow[t]{2}{*}{$\mathrm{FFcd}_{2}$} & & A & $\mathrm{S} 17^{\circ} 05^{\prime} 16^{\prime \prime}$ & & group with possible contribution from \\
\hline & & $\mathrm{B}$ & $\mathrm{W} 45^{\circ} 59^{\prime} 12^{\prime \prime}$ & & Urucuia Sandstone \\
\hline \multirow[t]{2}{*}{ RQo } & Quartzipsamment & A & $\mathrm{S} 17^{\circ} 25^{\prime} 48^{\prime \prime}$ & João Pinheiro & Tertiary and quaternary deposits \\
\hline & & $\mathrm{C}$ & $\mathrm{W} 46^{\circ} 04^{\prime} 36^{\prime \prime}$ & & associated with Urucuia sandstone \\
\hline
\end{tabular}

(1) According to Soil Taxonomy (approximate) - Soil Survey Staff (2010). 


\section{Construction of calibration curves for TDAAS Hg quantification}

Four soil samples with different textures (two clayey and two sandy) and different mineralogy, pre-heated to $500^{\circ} \mathrm{C}$ for elimination of natural $\mathrm{Hg}$, were used for the construction of the $\mathrm{Hg}^{2+}$ TDAAS calibration curves.

The B horizon of LVA, the A horizon of CXbe, and the $\mathrm{A}$ and $\mathrm{C}$ horizons of RQo were selected for use as a support for constructing the TDAAS calibration curves (Table 2). The use of soils with different mineralogies and textures seek to check for any influence of the solid matrix on the calibration curve.

Curves were prepared by adding increasing volumes $(10,20,50,70$, and $100 \mu \mathrm{L})$ of $\mathrm{Hg}^{2+}$ standard solution $\left(35 \mathrm{\mu g} \mathrm{mL}^{-1}\right)$ to $1.0000 \mathrm{~g}$ of pre-heated soils and then subjecting them to thermal desorption. After digitalization of the thermograms, the areas under the curves were obtained using Microcal Origin 8.0 software. Calibration curves were fitted by the least squares method by plotting the area under the curves versus $\mathrm{Hg}$ mass. All points of each curve were made in duplicate.

\section{Evaluation of accuracy and precision of the method}

Accuracy was evaluated by analyzing the CRMs, Montana Soil Nist-SRM $2711\left(6.25 \pm 0.19 \mathrm{\mu g} \mathrm{g}^{-1}\right.$ of $\mathrm{Hg}$ ) and River Sediment GBW-GBW 08301 RCV $8221\left(0.220 \pm 0.040 \mu g^{-1}\right.$ of $\left.\mathrm{Hg}\right)$. They were subjected to thermal desorption, in triplicate, and their $\mathrm{Hg}$ contents were calculated using the calibration curves. Two CRMs were analyzed, to cover different $\mathrm{Hg}$ concentration ranges. In addition, different masses of each standard were used to test the influence of mass on the accuracy of the results.

Samples of table 1 were also used to compare the results obtained by the proposed method, TDAAS, with the expected levels in the samples, calculated from DMA-80 analysis of the supernatants.
Comparison of the DMA and TDAAS methods was performed by the t-test of paired-samples at $95 \%$ confidence. The absorbance values of each sample were divided by the masses of the samples in such way that the area corrected by mass already resulted in $\mathrm{Hg}$ content ( $\mathrm{ng} \mathrm{g}^{-1}$ ) from the calibration curve (area of the thermogram versus $\mathrm{ng}$ of $\mathrm{Hg}$ ).

The accuracy of the proposed method was evaluated by the $\mathrm{Hg}$ recovery rate for the two CRMs and for the incubated samples. As recommended by Hibbert (1999), for the concentration range of this study, determinations with recoveries from 80 to $120 \%$ were considered accurate.

The precision of analysis of the CRMs and of the incubated samples was evaluated by the average of relative standard deviations of the measurements. Due to the impossibility of performing all determinations on the same day, replicates were made on different days. Thus, the precision found was an average of repeatability (on the same day) with the intermediate precision (on different days).

The precision of $\mathrm{Hg}$ determinations by the proposed method TDAAS was calculated by the relative standard deviation, or coefficient of variation $(\mathrm{CV})$, according to equation 1 :

$$
C V=\frac{S}{\bar{X}} \times 100
$$

where $\mathrm{S}$ is the standard deviation and $\bar{X}$ is the average among the results of the same sample.

\section{Limit of detection (LOD) and Limit of quantification (LOQ)}

According to the Inmetro guide (Inmetro, 2007), the limit of detection (LOD) is the lowest amount of analyte that can be reliably distinguished from zero. In contrast, the limit of quantification (LOQ) is the lowest concentration of analyte that can be determined with an acceptable level of uncertainty.

Determination of LOD was performed using seven readings of blanks (supports of the calibration curves).

Table 2. Identification, sampling site, and some chemical and physical (textural analysis) characteristics of soils used as a support for calibration $\operatorname{curves}^{(1)}$

\begin{tabular}{|c|c|c|c|c|c|c|c|c|c|c|c|}
\hline Soil cl & Horiz & Muni & Texture & Clay & Silt & Sand & $\mathbf{C}^{(3)}$ & $\mathrm{Fe}_{\mathrm{DCB}}{ }^{(4)}$ & $\mathrm{Fe}_{\mathrm{Ox}}{ }^{(5)}$ & $\mathrm{Al}_{\mathrm{DCB}}{ }^{(6)}$ & $\mathrm{Al}_{\mathrm{Ox}}{ }^{(7)}$ \\
\hline & & & & \multicolumn{8}{|c|}{$\mathrm{g} \mathrm{kg}^{-1}$} \\
\hline Typic Haplustox - LVA & B & Ponte Nova & Clas & 659.1 & 86.5 & 254.4 & $13.3(7)$ & $83.6(3)$ & $0.44(2)$ & $15.90(5)$ & $1.63(7)$ \\
\hline Oxic Eutric Haplustept - CXbe & A & Pedro Leopoldo & Clayey & 524.4 & 380.6 & 95.0 & $25.3(2)$ & $68.6(3)$ & $1.73(5)$ & $13.43(3)$ & $13.10(2)$ \\
\hline Quartzipsamment - RQo & A & João Pinheiro & Sandy & 110.1 & 36.9 & 853.0 & $9.07(2)$ & $2.73(2)$ & $0.20(1)$ & $0.92(2)$ & $0.73(3)$ \\
\hline Quartzipsamment - RQo & $\mathrm{C}$ & & Sandy & 148.5 & 29.8 & 821.8 & $5.06(3)$ & $2.17(3)$ & $0.18(1)$ & $0.71(1)$ & $0.48(3)$ \\
\hline
\end{tabular}

(1) Numbers in brackets represent the error in the last significant digit, estimated as the standard deviations from the mean of three replications. ${ }^{(2)}$ According to Soil Taxonomy (approximate) - Soil Survey Staff (2010). (3) Carbon content determined by the Walkley-Black method, according to Embrapa (1997). ${ }^{(4)}$ Iron oxides extracted by dithionite-citrate-bicarbonate. ${ }^{(5)}$ Iron oxides extracted by ammonium oxalate. ${ }^{(6)}$ Aluminum oxides extracted by dithionite-citrate-bicarbonate. ${ }^{(7)}$ Aluminum oxides extracted by ammonium oxalate. Extractions using dithionite-citrate-bicarbonate and ammonium oxalate were performed following Mehra and Jackson (1960) and McKeague and Day (1966), respectively. 
Areas under thermograms of blanks are converted to $\mathrm{Hg}$ content using the calibration curves. Then, LOD is calculated by equation 2 (Inmetro, 2007):

$$
L O D=\overline{X b}+3 S b
$$

To calculate LOQ, the same blank readings, converted to $\mathrm{Hg}$ content using the calibration curves, were increased by 5,6 , or 10 standard deviations, according to equations 3,4 , and 5 , as Inmetro guide recommendation, respectively.

$$
\begin{aligned}
& L O Q=\overline{X b}+5 S b \\
& L O Q=\overline{X b}+6 S b \\
& L O Q=\overline{X b}+10 S b
\end{aligned}
$$

where $\overline{X b}$ is the average of the blanks and $S b$ is the standard deviation of the blanks.

\section{RESULTS AND DISCUSSION}

\section{Calibration curves, linearity and matrix effects}

Eight calibration curves were constructed (four soils, each in duplicate) on different days using the following soils: the B horizon of LVA, the A horizon of CXbe, and the $\mathrm{A}$ and $\mathrm{C}$ horizons of RQo. The $\mathrm{Hg}^{2+}$ standard solutions were added to soils pre-heated to $500{ }^{\circ} \mathrm{C}$ to eliminate natural $\mathrm{Hg}$. $\mathrm{Hg}$ mass and the area of each standard are shown in table 3, and the thermograms of each calibration curve are shown in figure 2 .

The number of bands of the thermograms and the temperatures of $\mathrm{Hg}$ desorption are usually attributed to the presence of certain $\mathrm{Hg}$ species (Windmöller, 1996; Rumayor et al., 2013, 2015). Valle et al. (2005) demonstrated that $\mathrm{Hg}^{2+}$ absorbed into different mineral and organic soil constituents (kaolinite, gibbsite, hematite, ferrihydrite, goethite, and humic acids) showed characteristic thermal desorption profiles that can be used for $\mathrm{Hg}$ speciation in tropical soils. However, since the $\mathrm{Hg}$ thermal desorption of the calibration curves was performed just after pipetting of the standards and they were very acid, consisting of $\mathrm{Hg}^{2+}$ dissolved in nitric acid, a more intimate interaction between $\mathrm{Hg}^{2+}$ and soil, for example, by adsorption, is not expected. Thus, it is probable that the thermogram profiles are characteristic of the standard solution of $\mathrm{Hg}$ (II) nitrate, and not due to interactions between $\mathrm{Hg}$ and the soil matrix. However, two distinct patterns were observed when comparing the thermograms obtained from the clay soils in contrast with those obtained from sandy soils (Figure 2).

For sandy samples (A and C horizons of RQo; Figures $2 \mathrm{a}$ and $2 \mathrm{~b}$ ), two main bands were observed, one minor band centered around $180^{\circ} \mathrm{C}$, and another more intense band around $400{ }^{\circ} \mathrm{C}$. These results are similar to those found by Rumayor et al. (2013), who studied the thermal decomposition of $\mathrm{Hg}$ (II) nitrate with sandy soils. Thermograms of clayey soils (the B horizon of LVA and the A horizon of CXbe; Figures 2c and $2 \mathrm{~d}$ ) show a broadening of the first band, moving to a third plateau for more concentrated solutions. It seems, therefore, that there was some different type of interaction with clayey soils. In addition to exhibiting a third band of $\mathrm{Hg}$ thermal desorption, the clayey soils exhibited a shift of the bands of $\mathrm{Hg}$ release for higher temperatures. This behavior could suggest that the $\mathrm{Hg}^{2+}$ reduction process in clayey soils follows another mechanism that requires higher temperatures.

Another interpretation for this result considers physical, but not chemical or mineralogical, characteristics of the samples. If the furnace heat were more slowly transferred to the clayey samples, by lower thermal conductivity, curves similar to those obtained could be expected, with an enlargement of the initial band and a shift of the second band for higher temperatures. In fact, according to Nusier and Abu-Hamedeh (2003), samples of sandy soils they assessed showed thermal conductivities ranging from 1.9 to 2.7 times higher than clayey samples, which could explain the observed results.

Despite the differences in the shapes of the

\begin{tabular}{|c|c|c|c|c|c|c|c|c|c|}
\hline \multirow{3}{*}{$\begin{array}{l}\text { Volume of } 35 \mu \mathrm{g} \mathrm{mL}^{-1} \\
\mathrm{Hg}^{2+} \text { standard solution }\end{array}$} & \multirow{3}{*}{ Mercury mass } & \multicolumn{8}{|c|}{ Area under thermograms } \\
\hline & & \multicolumn{2}{|c|}{ LVA-B } & \multicolumn{2}{|c|}{ CXbe-A } & \multicolumn{2}{|c|}{ RQo-A } & \multicolumn{2}{|c|}{ RQo-C } \\
\hline & & R1 & R2 & R1 & R2 & R1 & R2 & R1 & R2 \\
\hline$\mu \mathrm{L}$ & ng & \multicolumn{8}{|c|}{ area unity } \\
\hline 10 & 350 & 59.72 & 0 & 67.46 & 42.20 & 154.2 & 439.1 & 172.5 & 118.2 \\
\hline 20 & 700 & 100.6 & 10.65 & 250.8 & 278.3 & 235.3 & 295.9 & 211.1 & 242.6 \\
\hline 50 & 1,750 & 319.3 & 341.7 & 605.8 & 638.7 & 656.3 & 529.7 & 538.8 & 641.6 \\
\hline 75 & 2,625 & 501.8 & 654.4 & 983.6 & 931.2 & 860.2 & 877.5 & 798.9 & 878.7 \\
\hline 100 & 3,500 & 666.8 & 1,010 & 1,201 & 1,224 & 1,105 & 1,174 & 1,223 & 1,176 \\
\hline
\end{tabular}
curves, the relationship between the areas under the

Table 3. Area under thermograms at each point of calibration curves in four soil samples (Typic Haplustox - LVA, Oxic Eutric Haplustept - CXbe, and Quartzipsamment - RQo 


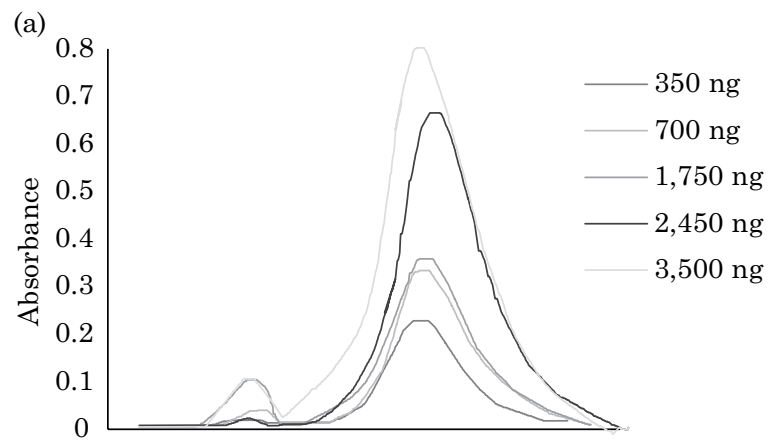

(c)

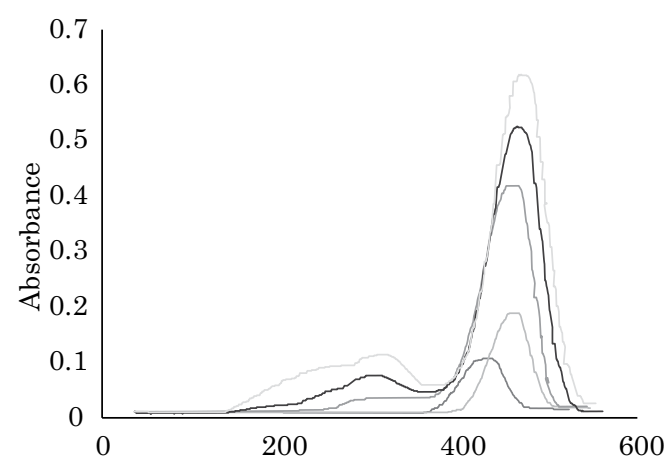

(b)

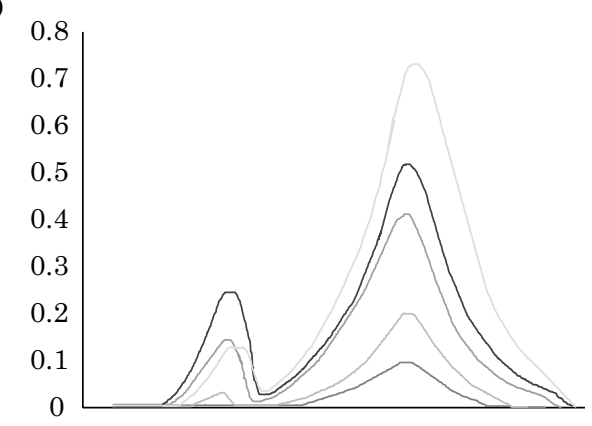

(d)

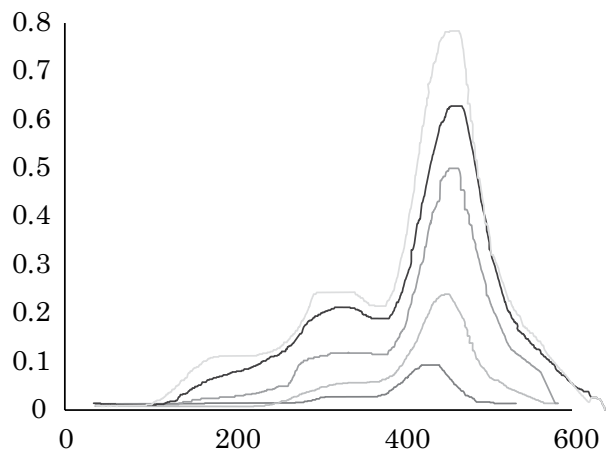

Temperature $\left({ }^{\circ} \mathrm{C}\right)$

Figure 2. Thermograms of mercury calibration curves in soils: (a) A horizon of Quartzipsamment - RQo; (b) C horizon of Quartzipsamment - RQo; (c) B horizon of Humic Xanthic Hapludox - LVA and (d) B horizon of Oxic Eutric Haplustept - CXbe.

curves and the $\mathrm{Hg}$ mass of each soil did not differ significantly among themselves, when considering replicates of the curves of a same soil, or curves from different soils. This shows that the matrix differences do not influence the total area of the curves, which suggests that the use of any soil as a support is acceptable for obtaining the calibration curves (Figure 3).

The curve replicates were well matched, as suggested by the uncertainty bars for each point, except for the first point of the curve obtained on the A horizon of the RQo and the curves obtained in the LVA soil (Figure 3). The latter even presents different slopes among the replicates (Figure 3a).

Discrepancies among replicates of LVA curves and the other curves were attributed to operational problems that the device had on the day when the LVA curve was constructed. Therefore, discrepancies in these curves were not considered to be due to the soil matrix.

Since the results of all of the curves, except for LVA, were very similar, we chose to work with an average curve, using the six replicates of the three other soils and discarding the results of the LVA curves. This average curve (Figure 3e) was used to calculate the amount of $\mathrm{Hg}$ recovered from the CRMs (Table 4) and from the samples from the $\mathrm{Hg}^{2+}$ adsorption experiment (Table 5).

The average curve used for $\mathrm{Hg}$ quantification showed excellent linearity, with $\mathrm{R}^{2}=0.9998$, even better than the coefficients of determination of the average curves for each soil, individually (Figure 3). This supports the idea that there is no contribution of the matrices to systematic errors, and that the fluctuations among different soils used for construction of calibration curves are absolutely randomized. This behavior and the fact that the total thermogram areas were not influenced by the sample matrix indicate the robustness of the method in relation to the mineralogical and textural characteristics of soil samples. In fact, the $\mathrm{Hg}$ contents (recovered from very different samples) by the average curve showed that there is no trend in relation to soil type, mineralogy, or texture (Table 5). Even the Oxisols, similar to the matrix of the discarded curve, showed a satisfactory $\mathrm{Hg}$ recovery for a method to be considered exact, between 80 and $120 \%$, according to Hibbert (1999).

This way of constructing the calibration curve provides numerous advantages over the use of certified material. It can be done in the same soil 
(a)

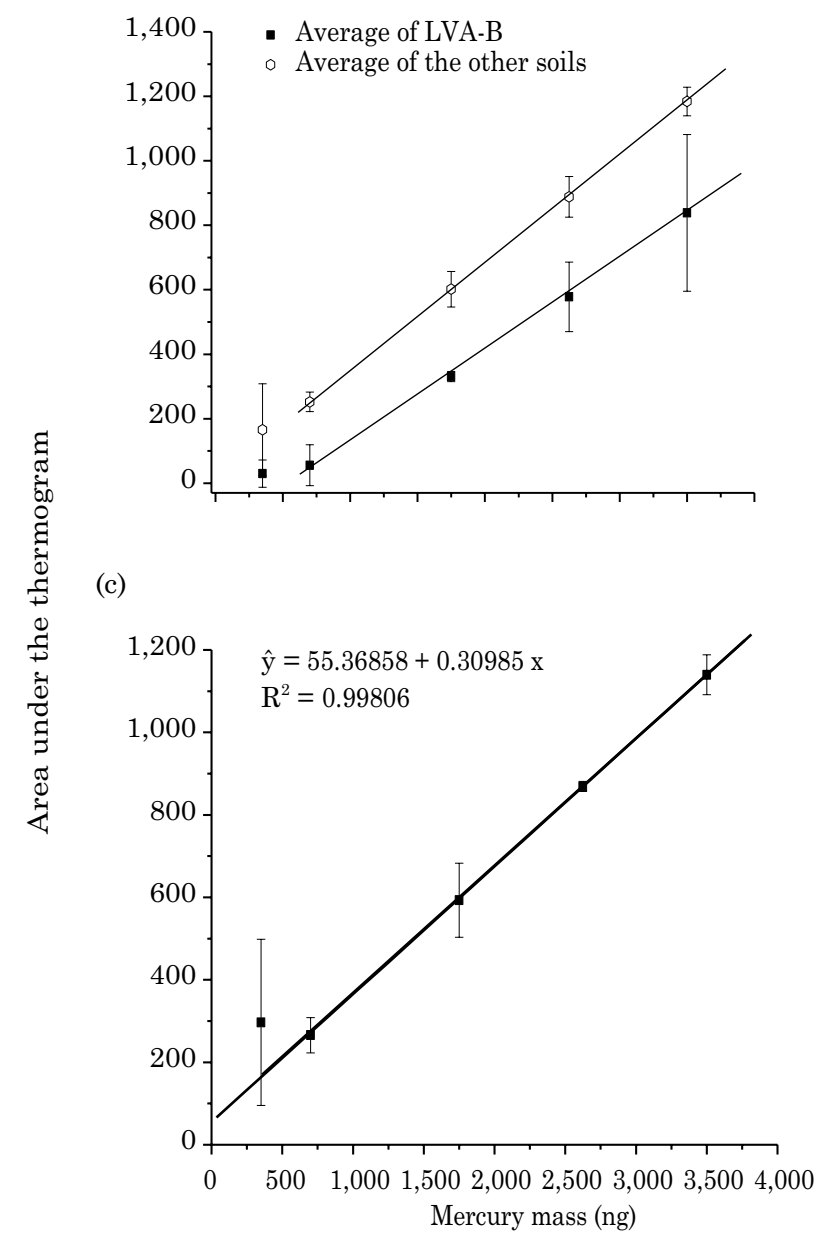

(b)

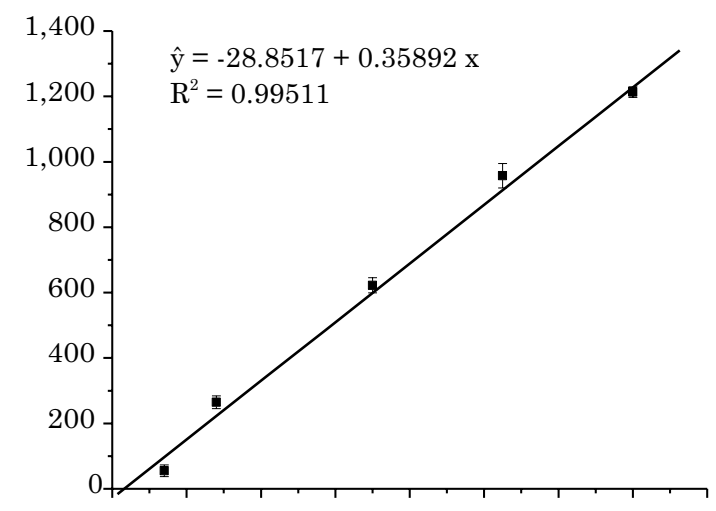

(d)

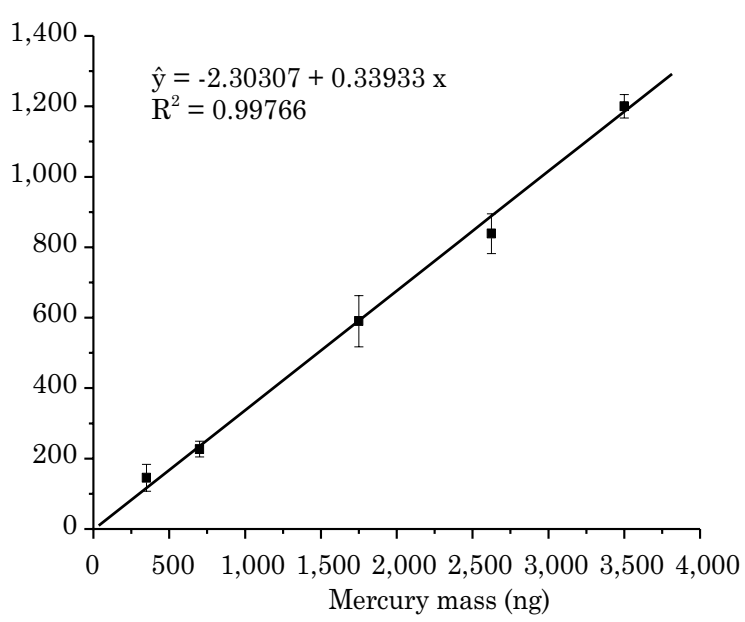

(e)

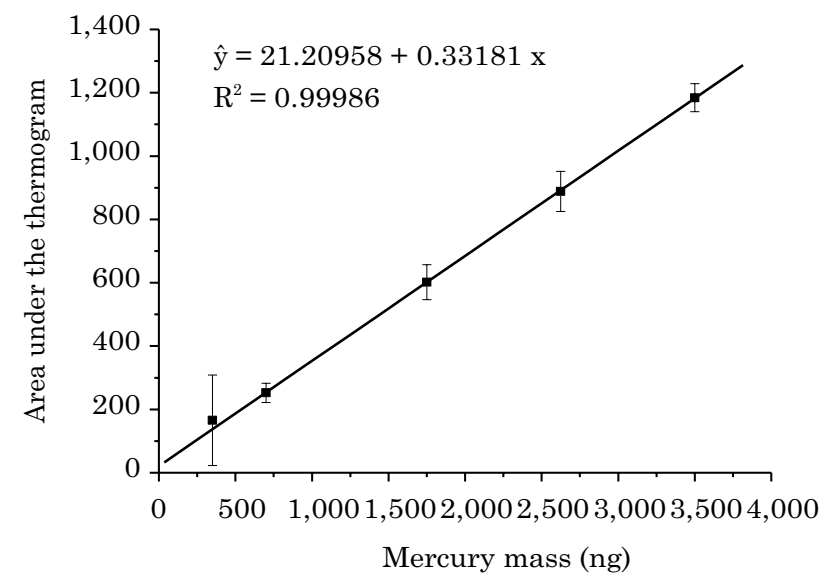

Figure 3. Mercury calibration curves by thermal desorption associated with atomic absorption spectrometry in different matrices: (a) average of B horizon of Humic Xanthic Hapludox - LVA-B and average of the other soils, (b) average of B horizon of Oxic Eutric Haplustept - CXbe-B, (c) average of A horizon of Quartzipsamment - RQo-A, (d) average of C horizon of Quartzipsamment - RQo-C, and (e) average of CXbe-B, RQo-A, and RQo-C. The curve of each soil is constituted by the average of two replicates and the (e) curve is constituted by the average of six replicates (two from each soil). 
Table 4. Concentration and recovery percentage of mercury in certified reference materials by the proposed thermal desorption associated with atomic absorption spectrometry method

\begin{tabular}{|c|c|c|c|c|c|c|c|}
\hline \multirow{2}{*}{$\operatorname{CRM}^{(1)}$} & \multirow{2}{*}{$\begin{array}{l}\text { Mass of } \\
\text { CRM }\end{array}$} & \multirow{2}{*}{$\begin{array}{l}\text { Area under } \\
\text { thermogram }\end{array}$} & \multirow{2}{*}{$\begin{array}{l}\text { Mass of mercury } \\
\text { average curve }\end{array}$} & \multirow{2}{*}{\multicolumn{2}{|c|}{ Recovery }} & \multicolumn{2}{|l|}{ Average } \\
\hline & & & & & & Concentration \pm standard deviation & Recovery \\
\hline \multirow{4}{*}{$\begin{array}{l}\text { Montana } \\
\text { soil }\end{array}$} & $\mathrm{g}$ & area unity & ng & $\mu \mathrm{g} \mathrm{g}^{-1}$ & $\%$ & $\mu g^{-1}$ & $\%$ \\
\hline & 0.1036 & 222.66 & 607.12 & 5.86 & 93.76 & $5.89 \pm 0.07$ & $94.28 \pm 1.13$ \\
\hline & 0.2941 & 604.13 & 1756.79 & 5.97 & 95.58 & & \\
\hline & 0.4156 & 827.14 & 2428.89 & 5.84 & 93.51 & & \\
\hline \multirow{3}{*}{$\begin{array}{l}\text { River } \\
\text { sediment }\end{array}$} & 0.9047 & 80.212 & 177.82 & 0.197 & 89.34 & $0.233 \pm 0.062$ & $106 \pm 28$ \\
\hline & 0.9198 & 114.37 & 280.76 & 0.305 & 138.75 & & \\
\hline & 1.2414 & 102.95 & 246.35 & 0.198 & 90.20 & & \\
\hline
\end{tabular}

Table 5. Mercury levels determined by thermal desorption associated with atomic absorption spectrometry in lyophilized soil samples after $\mathrm{Hg}^{2+}$ adsorption experiments, and the contents estimated by the DMA in the supernatants from the same experiment

\begin{tabular}{|c|c|c|c|c|c|c|c|}
\hline \multirow{2}{*}{ Soil } & \multirow{2}{*}{ Horizon } & \multirow{2}{*}{ Texture } & \multirow{2}{*}{ Area/mass } & \multicolumn{2}{|c|}{ Mercury content } & \multirow{2}{*}{ Recovery } & \multirow{2}{*}{$\begin{array}{c}\text { Absolute } \\
\text { difference }^{(3)}\end{array}$} \\
\hline & & & & Calculated & Expected $^{(2)}$ & & \\
\hline & & & & \multicolumn{2}{|c|}{$\mu \mathrm{g} \mathrm{g}^{-1}$} & $\%$ & $\mu \mathrm{g} \mathrm{g}^{-1}$ \\
\hline NVef & $\mathrm{A}$ & Clayey & 555.54 & 1.610 & 1.952 & 82.49 & -0.3417 \\
\hline NVef & $\mathrm{A}$ & Clayey & $4,887.73$ & 14.667 & 19.885 & 73.76 & -5.2182 \\
\hline NVef & $\mathrm{A}$ & Clayey & $15,331.66$ & 46.142 & 38.945 & 118.48 & 7.1963 \\
\hline CXbe & $\mathrm{B}$ & Clayey & 794.90 & 2.332 & 1.972 & 118.22 & 0.3594 \\
\hline $\mathrm{LVd}$ & B & Clayey & 620.98 & 1.808 & 1.968 & 91.86 & -0.1602 \\
\hline LVad & $\mathrm{A}$ & Clayey & 498.59 & 1.439 & 1.972 & 72.94 & -0.5338 \\
\hline $\mathrm{LVj}$ & $\mathrm{A}$ & Medium & 742.90 & 2.175 & 1.889 & 115.12 & 0.2857 \\
\hline $\mathrm{LVj}$ & $\mathrm{B}$ & Medium & 573.92 & 1.666 & 1.936 & 86.05 & -0.2701 \\
\hline $\mathrm{FFcd}_{2}$ & B & Medium & 705.35 & 2.062 & 1.967 & 104.84 & 0.0951 \\
\hline $\mathrm{FFcd}_{1}$ & $\mathrm{~A}$ & Medium & 677.82 & 1.979 & 1.918 & 103.19 & 0.0613 \\
\hline $\mathrm{FFcd}_{2}$ & $\mathrm{~A}$ & Medium & 483.11 & 1.392 & 1.899 & 73.29 & -0.5073 \\
\hline RQo & A & Sandy & 710.77 & 2.078 & 1.787 & 116.30 & 0.2913 \\
\hline RQo & $\mathrm{C}$ & Sandy & 821.31 & 2.411 & 1.891 & 127.53 & 0.5206 \\
\hline \multirow[t]{2}{*}{ PVA } & $\mathrm{A}$ & Clayey & 654.48 & 1.909 & 1.892 & 100.88 & 0.0167 \\
\hline & & & & & \multicolumn{2}{|c|}{ Average difference } & 0.1282 \\
\hline
\end{tabular}

(1) Mercury content calculated using the average calibration curve. Values in bold indicate that the results are in the acceptable range (between 80 and $120 \%$ of the expected value). ${ }^{(2)}$ Mercury content estimated by the adsorption experiment, calculated as the difference between the initial added mercury content and the final mercury content in the supernatant, after adsorption, measured by the DMA. ${ }^{(3)}$ Difference between the calculated mercury content and the expected mercury content.

matrix under study. It is not expensive, since it does not use high-cost certified materials. It is not necessary to accurately weigh the soil that supports the standard solution, and the same soil support can be used for all curve points, especially when the measurements are made from the lowest to the highest $\mathrm{Hg}$ level.

\section{Accuracy and precision of the method}

The accuracy of the method was verified by analyzing two CRMs with different $\mathrm{Hg}$ concentration ranges (Table 4) and by comparing the contents recovered after the adsorption of $\mathrm{Hg}^{2+}$ in samples of various soil types, textures, and mineralogies. To evaluate the $\mathrm{Hg}$ recovery from the samples, the results calculated by TDAAS calibration curves were compared with the levels expected in the samples as calculated by DMA-80 analysis of the supernatants (Table 5). The t-value was calculated by equation 6 (where $\bar{X} d=0.1282$ and $S d=2.483$ ) and the calculated t-value $(0.186)$ was less than tabulated t-value $(2.18$, at $95 \%$ confidence, $\mathrm{n}=14)$. Therefore, 
the comparison between the DMA and TDAAS methods for these samples do not show statistical differences when paired-samples were tested by the t-test at $95 \%$ confidence.

$$
t=\overline{X d} \cdot \sqrt{n} / S d
$$

where $\bar{X} d$ and $S d$ are the average and the standard deviation, respectively, of the differences between the expected masses and determined masses.

Determinations with $\mathrm{Hg}$ recoveries from 80 to $120 \%$ were considered to be exact (Hibbert, 1999), both for the CRMs and for the samples from the $\mathrm{Hg}^{2+}$ adsorption experiment.

The recovery percentages from CRMs were $94.28 \pm 1.13 \%$ for Montana Soil (Hg certified content of $\left.6.25 \pm 0.19 \mathrm{\mu g} \mathrm{g}^{-1}\right)$ and $106 \pm 28 \%$ for River Sediment (Hg certified content of $0.220 \pm 0.040 \mathrm{\mu g} \mathrm{g}^{-1}$ ) (Table 4). For both CRMs, the recovery percentages were very close to $100 \%$, and the standard deviation of the material with lower $\mathrm{Hg}$ content was far superior to the other, as expected. However, this higher standard deviation was mainly due to the discrepancy in one of the readings of this CRM, as shown in table 4 . As the $\mathrm{Hg}$ content in River Sediment CRM is much smaller than in the Montana Soil CRM, the sample masses of River Sediment were very high, which is not ideal given the size of the sample holder.

Since the results of the three masses of Montana Soil CRM were proportional, it would be possible to obtain a calibration curve with this material, with excellent linearity $(R=0.9994)$ and angular and linear coefficients similar to the curve generated by standards in solution, as shown in figure 4 . Although this type of calibration curve can be made, it is not very feasible because of the high cost of the $\mathrm{CRMs}$, and it is unnecessary since it has already been shown that the results obtained with standard solutions on solid supports were similar.

The $\mathrm{Hg}$ levels of samples (from adsorption experiments) obtained by the TDAAS method were compared to expected levels calculated from the DMA analysis of the supernatant of the adsorption experiments (Table 5). It was found that ten out of the 14 samples showed recovery percentages between 80 and $120 \%$. Among the four samples that showed recovery percentages outside the acceptable range, three of them showed recoveries around $73 \%$, while the fourth sample showed $127 \%$ recovery. Although the recovery percentages of these four samples are outside the range considered acceptable for exact methods (Hibbert, 1999), these results were very close to the limits of acceptability.

No trend or systematic error was observed in relation to the nature of the samples, texture, soil class, or $\mathrm{Hg}$ content, thus dismissing any interference of the matrix on analysis of total metal content. However, it is necessary to investigate

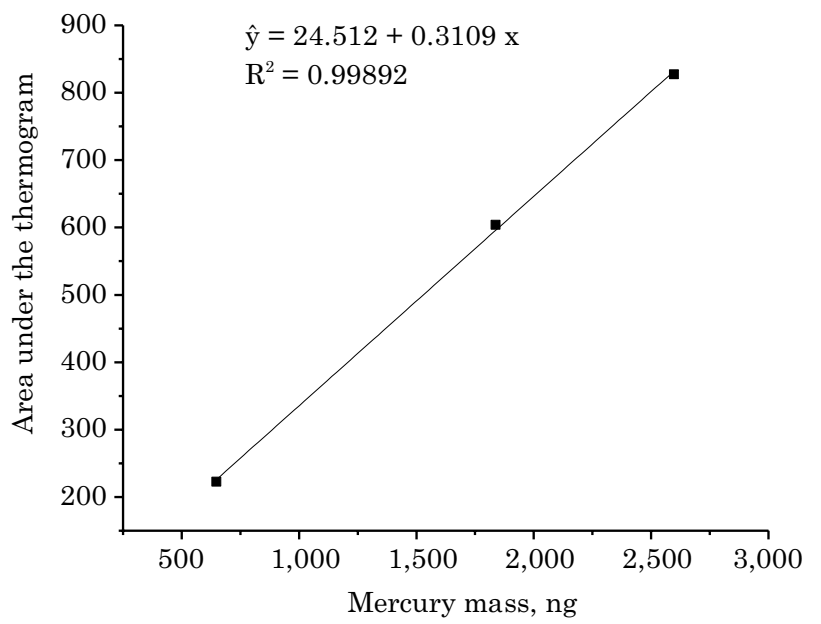

Figure 4. Curve of the area under the thermogram as a function of mercury mass from certified reference material Montana Soil Nist-SRM 2711 $\left(6.25 \pm 0.19 \mathrm{\mu g} \mathrm{g}^{-1}\right.$ of mercury).

the influence of the thermal conductivities of the samples with different textures for evaluation of $\mathrm{Hg}$ speciation, which is not the object of this study.

The CV values of CRMs were $1.1 \%$ for Montana Soil and $26 \%$ for River Sediment. In the case of samples from the $\mathrm{Hg}^{2+}$ adsorption experiment, the CV values range from 3 to $8 \%$, which is considered very satisfactory.

In order to illustrate the reproducibility of thermal desorption analysis, the thermograms of some duplicates of NVef subjected to adsorption of different $\mathrm{Hg}^{2+}$ levels are shown (Figure 5). Except for the sample with a lower $\mathrm{Hg}$ level (Figure 5a), which showed low reproducibility, the replicates are almost superimposed for all other thermograms.

\section{Limit of detection (LOD) and Limit of quantification (LOQ)}

The limits of detection (LOD) and quantification (LOQ) were calculated according to the Inmetro guide (Inmetro, 2007). For seven blanks, the average and the standard deviation calculated were -42.99 $\mathrm{ng} \mathrm{g}^{-1}$ and $33.11 \mathrm{ng} \mathrm{g}^{-1}$, respectively.

The LOD calculated was $56.34 \mathrm{ng} \mathrm{g}^{-1}$ (ppb) and the LOQs calculated were 122.56, 155.67 and $288.10 \mathrm{ng} \mathrm{g}^{-1}$ of $\mathrm{Hg}$ according to equations 3, 4 and 5, respectively. These values are calculated only by the signs of the blanks and do not necessarily correspond to the reality for LOQ values. This is confirmed by the successful result of the proposed method for determining the $\mathrm{Hg}$ content in the River Sediment CRM. The Hg content of this CRM $\left(220 \mathrm{ng} \mathrm{g}^{-1}\right)$ is lower than the highest calculated LOQ $\left(288 \mathrm{ng} \mathrm{g}^{-1}\right)$, which shows that the true LOQ of the method is below this value. 
(a)

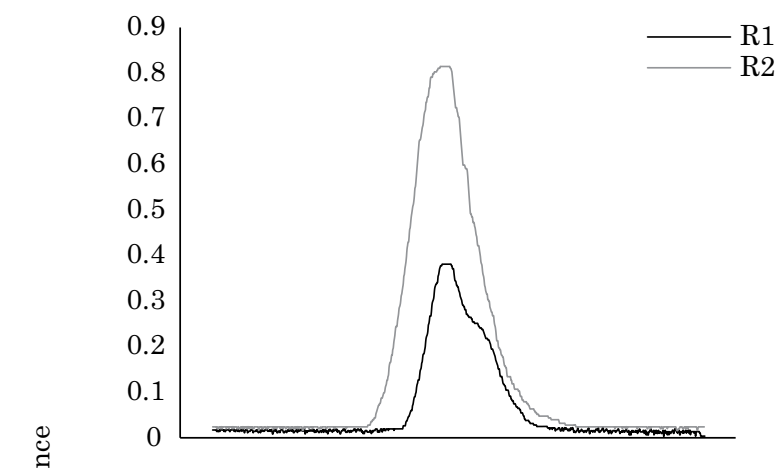

(c)

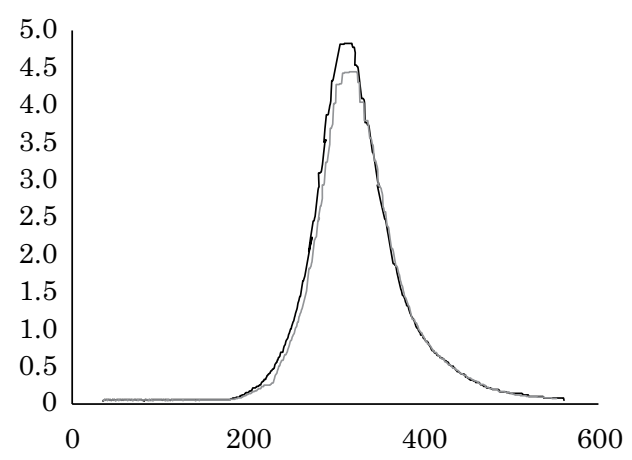

(b)

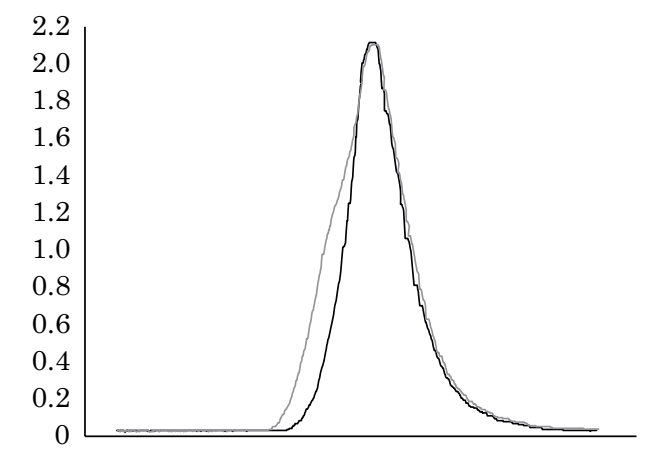

(d)

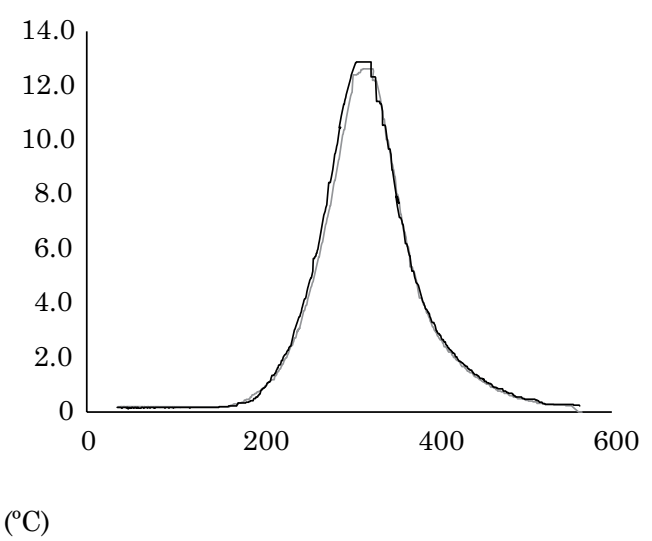

Figure 5. Thermograms of samples of Typic Rhodudalf (NVef) soil subjected to adsorption of $\mathrm{Hg}^{2+}$ solution at the following concentrations: (a) $0.1000 \mathrm{~g} \mathrm{~mL}^{-1}$, (b) $0.5000 \mathrm{~g} \mathrm{~mL}^{-1}$, (c) $1.000 \mathrm{gg} \mathrm{mL}^{-1}$, and (d) $2.000 \mathrm{\mu g} \mathrm{mL}^{-1}$. In the key, $R 1$ and $R 2$ represent replicates 1 and 2 , respectively, measured on different days.

Although official manuals of validation of analytical methods accept LOQ calculations only with blank measures, the true LOQ is obtained by measuring increasingly diluted samples and checking whether they are still within an acceptable range of error and linearity. In the absence of this assessment and due to success in analysis of River Sediment, we adopted the intermediate value (155.67 $\left.\mathrm{ng} \mathrm{g}^{-1}\right)$ as the LOQ for the TDAAS method.

Although we did not assess the limit of linearity of the curve, the highest value of the range tested $\left(3,500 \mathrm{ng} \mathrm{g}^{-1}\right)$ did not show any deviation from linearity, and the analysis of one NVef soil sample, with $38.945 \mathrm{ng} \mathrm{g}^{-1}$ of $\mathrm{Hg}$ (nearly $39 \mathrm{\mu g} \mathrm{g}^{-1}$ ), was successful. Both results suggest that the linearity of the method achieves at least about $40,000 \mathrm{ng} \mathrm{g}^{-1}\left(40 \mathrm{\mu g} \mathrm{g}^{-1}\right)$.

Thus, the method proposed is able to analyze $\mathrm{Hg}$ in much more concentrated samples than DMA-80, which is linear from 2 to $2,000 \mathrm{ng} \mathrm{g}^{-1} \mathrm{of} \mathrm{Hg}$. Therefore, it is a more suitable technique for contaminated samples, as well as for uncontaminated samples, such as the ones from the Quadrilátero Ferrífero region of Minas Gerais, Brazil, which can reach about $5 \mathrm{\mu g} \mathrm{g}^{-1}$. As for the lower limit, despite not achieving the same LOQ of the DMA, the method proved to be useful for samples up to $200 \mathrm{ng} \mathrm{g}^{-1}$ $\left(0.2 \mathrm{~kg} \mathrm{~g}^{-1}\right)$, with the advantage of TDAAS being a cheaper technique than the DMA in regard to acquisition and operational maintenance.

\section{Final considerations}

The TDAAS is not only a quantitative technique for determining total $\mathrm{Hg}$ content, like the DMA, but it is also a technique that may perform $\mathrm{Hg}$ speciation in a short period (20 $\mathrm{min}$ ) when compared with sequential extraction. In addition, it does not generate waste, as it eliminates digestion and pretreatment of the samples.

As the TDAAS equipment does not need to be sophisticated, obsolete atomic absorption spectrometers can be reused since the optical system and the background correction work well and it is possible to acquire the data of absorbance as a function of time. This data can be acquired by the software of the equipment for analysis by graphite furnace, even if the equipment does not have this device.

Considering that the results are highly reproducible on different days, it would be possible to use the same calibration curve for a long period, simply checking standard measures from time to time. 


\section{CONCLUSIONS}

The proposed method based on the TDAAS technique proved to be accurate and precise from evaluation of certified reference materials.

The construction of calibration curves with equivalent results from matrices of different soil types and textures showed that quantitative determination is independent of the sample matrices and that the proposed method is robust.

The method is adequate for the construction of calibration curves using both the expensive certified materials, as well as the standard solution of $\mathrm{Hg}$, at very low cost, pipetted on $\mathrm{Hg}$-free soil matrices.

$\mathrm{Hg}$ determination of samples from the adsorption experiment of $\mathrm{Hg}^{2+}$ in different soil types, textures, and $\mathrm{Hg}^{2+}$ contents was considered accurate for $10 \mathrm{out}$ of the 14 samples tested, and the results obtained were not statistically different at $95 \%$ confidence from values provided by the DMA technique.

\section{REFERENCES}

Aston SR, Riley JP. The determination of mercury in rocks and sediments. Anal Chim Acta. 1972;59:349-54.

Companhia de Tecnologia de Saneamento Ambiental - Cetesb. Dispõe sobre a aprovação dos Valores Orientadores para Solos e Águas Subterrâneas no Estado de São Paulo - 2005, em substituição aos Valores Orientadores de 2001, e dá outras providências. Decisão de diretoria $n^{0} 195-2005$-E, de 23 de nov. de 2005 [Accessed on Oct 7, 2014]. Available at: http://www.cetesb. sp.gov.br/media/files/Solo/relatorios/tabela_valores_2005.pdf.

Departamento Nacional de Produção Mineral - DNPM. Anuário mineral brasileiro 2010. Brasília: 2010 [Accessed on Oct 7, 2014]. Available at: http://www.dnpm.gov.br/relatorios/amb/ Completo_2010.pdf.

Durão Júnior WA, Palmieri HE, Trindade MC, Aquino Branco OE, Carvalho Filho CA, Fleming PM, Silva JB, Windmöller CC. Speciation, distribution, and transport of mercury in contaminated soils from Descoberto, Minas Gerais, Brazil. J Environ Monit. 2009;11:1056-63.

Empresa Brasileira de Pesquisa Agropecuária - Embrapa. Centro Nacional de Pesquisa de Solos. Manual de métodos de análise de solo. $2^{\text {a }}$.ed. Rio de Janeiro: Embrapa Solos; 1997.

Henry HG, Stever KR, Barry WL, Heady HH. Determination of mercury in low-grade ores. Appl Spectrosc. 1972;26:288-93.
Hibbert DB. Method validation of modern analytical techniques. Accred Qual Assur. 1999;4:352-6.

Kim CS, Rytuba JJ, Brown Jr GE. Geological and anthropogenic factors influencing mercury speciation in mine wastes: an EXAFS spectroscopy study. Appl Geochem. 2003;147:1-15.

Instituto Nacional de Metrologia - Inmetro. Orientação sobre validação de métodos de ensaios químicos. (Documento de caráter orientativo. DOQ-CGCRE-008. Revisão 02 Jun. 2007).

Lidums V. Determination of mercury in small quantities by direct combustion combined with cold vapor atomic absorption. Chem Scripta. 1972;2:159-63.

Mckeague JA, Day JH. Dithionite and oxalate-extractable Fe and $\mathrm{Al}$ as aids in differentiating various classes of soil. Can J Soil Sci. 1966;46:13-22.

Mehra OP, Jackson ML. Iron oxide removal from soils and clays by a dithionite-citrate system buffered with sodium bicarbonate. Clays Clay Miner. 1960;7:317-27.

Mello JWV, Abrahão WAP. Solos contaminados no Brasil. O desafio de definir valores de referência. B Inf SBCS. 2013;38:12-7.

Nusier OK, Abu-Hamedeh NH. Laboratory techniques to evaluate thermal conductivity for some soils. Heat Mass Transfer. 2003;39:119-23.

Preston W, Nascimento CWA, Biondi CM, Souza Junior VS, Silva WR, Ferreira HA. Valores de referência de qualidade para metais pesados em solos do Rio Grande do Norte. R Bras Ci Solo. 2014;38:1028-37.

Rumayor M, Diaz-Somoano M, Lopez-Anton MA, Martinez-Tarazona MR. Mercury compounds characterization by thermal desorption. Talanta. 2013;30:318-22.

Rumayor M, Diaz-Somoano M, Lopez-Anton MA, Martinez-Tarazona MR. Application of thermal desorption for the identification of mercury species in solids derived from coal utilization. Chemosphere. 2015;119:459-65.

Soil Survey Staff. Keys to soil taxonomy. Washington: USDA/NRCS; 2010.

UNEP Chemicals Branch. The global atmospheric mercury assessment: sources, emissions and transport. Geneva: UNEP-Chemicals; 2008.

Valle CM, Augusti R, Santana GP, Egreja Filho FB, Windmöller CC. Speciation and quantification of mercury in Oxisol, Ultisol and Spodosol from Amazon (Manaus, Brazil). Chemosphere. 2005;58:779-92.

Wang D, Shi X, Wei S. Accumulation and transformation of atmospheric mercury in soil. Sci Total Environ. 2003;304:209-14.

Windmöller CC. Especiação de mercúrio em solos contaminados por análise de termodessorção acoplada à absorção atômica [tese]. Campinas: Universidade Estadual de Campinas; 1996. 